\title{
MAKALAH
}

YAYASAN

Untuk memenuhi tugas mata kuliah

\section{ASPEK HUKUM DALAM BISNIS}

Yang di bimbing

Bu. Retno Sari Dewi, S.H, M.M

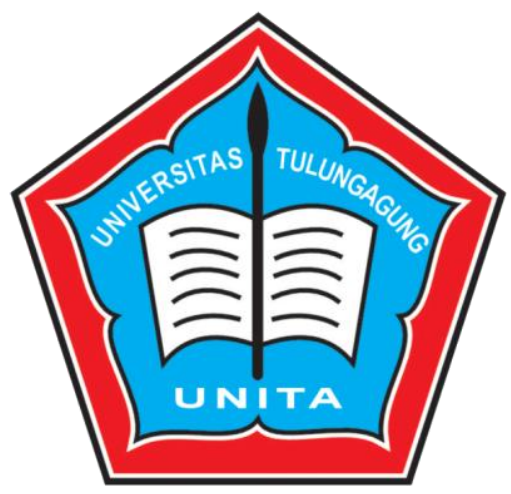

Disusun Oleh

KELOMPOK 1

1. ATALYAPERMATA PUTRI ZADOK (1860301100009)

2. EVITA EGA RAMADANI (1860301100059)

3. MOHAMMAD KHUBBI NUR AMAMI (1860301100005)

4. NIKITA LARASATI PURBANINGRUM (1860301100020)

5. ROYAN Z BACHTIAR (1860301100008)

6. YOGA DWI KUNCAH (1860301100025)

UNIVERSITAS TULUNGAGUNG

FAKULTAS EKONOMI

PRODI AKUTANSI

2019/2020 


\section{BAB I \\ PENDAHULUAN}

\section{LATAR BELAKANG}

Yayasan saat ini sulit dibedakan dengan lembaga yang berorientasi laba. Bentuk hukum yayasan telah dijadikan payung untuk menyiasati berbagai aktivitas diluar bidang sosial, keagamaan, kemanusiaan, kesehatan, serta pendidikan dan persoalan ini telah mendapat sorotan tajam dari berbagai pihak, terutama pihakperpajakan. Dampaknya, sistem dunia usaha menghadapi resiko penghancuran melalui regulasi serta kepatutan yang bersifat umum. Berbagai fakta yang ada menunjukan bahwa kecenderungan pendidikan yayasan adalah untuk berlindung dibalik status badan hukum yayasan, dan bukan wadah pengembangan wadah sosial, keagaman, dan kemanusiaan. Selain itu tujuan kecenderungan ini biasanya berakhir dengan interprestasi, memperkaya diri para pendiri, pengurus, dan pengawas.

Sejalan dengan kecenderungan tersebut, berbagai masalah yayasan, mulai muncul seperti kegiatan yayasan yang tidak sesuai dengan maksud dan tujuan yang tercantum dalam anggaran dasar, sengketa antara pengurus dengan pendiri atau pihak lain, dan dugaan bahwa yayasan digunakan untuk menampung kekayaan para pendiri atau pihak lain yang diperoleh dengan cara melawan hukum. Banyaknya masalah tersebut memunculkan kebutuhan akan hukum positif atau landasan hukum yuridis.

Dalam rangka penerapan prinsip keterbukaan dan akuntabilitis pada masyarakat, manajemen yayasan melakukan pembenahan administrasi termasuk publikasi pertanggungjawaban laporan keuangan setiap tahun.

\section{RUMUSAN MASALAH}

1. Apa pengertian yayasan?

2. Siapa yang menjadi pengurus yayasan?

3. Apa perbedaan yayasan dengan perkumpulan?

4. Apa sifat dan karakteristik yayasan?

5. Bagaimana kedudukan hukum yayasan?

6. Bagaimana contoh masalah yayasan dalam prakteknya? 


\section{TUJUAN}

1. Untuk mengetahui pengertian yayasan?

2. Untuk mengetahui Siapa yang menjadi pengurus yayasan?

3. Untuk mengetahui perbedaan yayasan dengan perkumpulan?

4. Untuk mengetahui sifat dan karakteristik yayasan?

5. Untuk mengetahui kedudukan hukum yayasan?

6. Untuk mengetahui contoh masalah yayasan dalam prakteknya? 


\section{BAB II}

\section{PEMBAHASAN}

\section{PENGERTIAN DAN RUANG LINGKUP YAYASAN}

Yayasan adalah suatu badan hukum yang mempunyai maksud dan tujuan bersifat sosial, keagamaan dan kemanusiaan, didirikan dengan memperhatikan persyaratn formal yang ditentukan dalam undng-undang. Di Indonesia, yayasan diatur dalam undangundang no. 28 tahun 2014 tentang perubahan atas UU No 16 tahun 2001 tentang yayasan.

Rapat paripurna DPR pada tanggal 7 september 2004 menyetujui undang-undang ini, dan Presiden RI Megawati Soekarno Putri mengesahkannya pada tanggal 6 Oktober 2004. Menurut UU No. 16 tahun 2001, sebagai dasar hukum positif yayasan. Pengertian yayasan adalah badan hukum yang kekayaanya terdiri dari kekayaan yang dipisahkan dan diperuntukkan untuk mencapai tujuan tertentu dibidang sosial, keagamaan, dan kemanusiaan. Yayasan dapat melakukan kegiatan usaha untuk menunjang pencapaian maksud dan tujuan dengan cara mendirikan badan usaha atau ikut serta dalam suatu badan usaha.

\section{PENGURUS YAYASAN}

Dewan Pembina

1. Guna memaksimalkan tanggung jawab dan proses pemungutan suara maka sebaiknya anggota Dewan Pengurus Yayasan terdiri dari sekurang-kurangnya 3 orang dan dalam pertemuan telah diputuskan untuk ditetapkan jumlah Dewan Pembina sebanyak 3 orang.

2. Yang dapat diangkat sebagai anggota Pembina adalah orang perseorangan sebagai Pendiri Yayasan dan/atau mereka yang berdasarkan keputusan rapat anggota Pembina dinilai mempunyai dedikasi yang tinggi untuk mencapai maksud dan tujuan Yayasan.

3. Anggota Pembina tidak diberi gaji dan atau tunjangan oleh Yayasan.

4. Masa jabatan Dewan Pembina tidak ditentukan lamanya.

5. Anggota Dewan Pembina tidak boleh merangkap menjadi anggota Dewan Pengurus maupun Dewan Penasihat.

6. Pembina berwenang bertindak untuk dan atas nama Yayasan.

7. Pembina berwenang untuk mengubah anggaran dasar yayasan.

8. Pembina bertanggung jawab melaksanakan rapat tahunan yayasan.

9. Pembina berhak untuk memberhentikan Dewan Pengurus yayasan.

10. Pembina berhak untuk memberhentikan Dewan Penasihat yayasan. 
11. Pembina berhak untuk menetapkan kebijakan umum yayasan

12. Pembina berhak melakukan pembagian tugas dan wewenang setiap anggota Pengurus dengan berdasarkan Rapat Pembina.

\section{BIAYA PENDIRIAN YAYASAN}

Biaya-biaya

Biaya yang harus dikeluarkan untuk pengesahan atas pendirian yayasan :
a. Akta pendirian yayasan
Rp. 500.000
b. PNBP persetujuan atas pemakaian nama
Rp. 100.000
c. PNBP atas pengesahan akta pendirian
Rp. 250.000
d. PNBP TBNRI
Rp. 300.000
e. Pengiriman berkas ke Jakarta
Rp. 350.000
f. Biaya pengurusan
Rp. 1.000 .00
$+-$
Rp. 2.500 .00

\section{PERBEDAAN YAYASAN DAN PERKUMPULAN}

Yayasan merupakan suatu bagian dari Perkumpulan yang berbentuk Badan Hukum dengan pengertian/definisi yang dinyatakan dalam Pasal 1 butir 1 Undang-Undang No. 16 Tahun 2001 tentang Yayasan yaitu suatu Badan Hukum yang terdiri atas kekayaan yang dipisahkan dan diperuntukan untuk mencapai tujuan tertentu di bidang sosial, keagamaan dan kemanusiaan yang tidak mempunyai anggota. Perkumpulan dalam pengertian ini terbagi atas 2 (dua) macam, yaitu:

1. Berbentuk Badan Hukum, seperti Perseroan Terbatas, Koperasi dan Perkumpulan saling Menanggung;

2. Tidak berbentuk Badan Hukum, seperti Persekutuan Perdata, CV dan Firma.

Perbedaan antara Perkumpulan dan Yayasan adalah sebagai berikut: Perkumpulan :
a. Bersifat dan bertujuan komersial;
b. Mementingkan keuntungan ( profit oriented );
c. Mempunyai anggota.

Yayasan

a. Bersifat dan bertujuan sosial, keagamaan dan kemanusiaan;

b. Tidak semata-mata mengutamakan keuntungan atau mengejar/mencari keuntungan dan/atau penghasilan yang sebesar-besarnya;

c. Tidak mempunyai anggota. 
Yayasan sebagai suatu Badan Hukum mampu dan berhak serta berwenang untuk melakukan tindakan-tindakan perdata. Pada dasarnya keberadaan Badan Hukum bersifat permanen, artinya Badan Hukum tidak dapat dibubarkan hanya dengan persetujuan para pendiri atau anggotanya. Badan Hukum hanya dapat dibubarkan jika telah dipenuhi segala ketentuan dan persyaratan yang ditetapkan dalam anggaran dasarnya. Hal tersebut sama kedudukannya dengan Perkumpulan yang berbentuk berbadan hukum, dimana dipandang sebagai subyek hukum karena dapat melakukan perbuatan hukum, menyandang hak dan kewajiban, dapat digugat maupun menggugat di Pengadilan. Sehingga dapat disimpulkan bahwa Yayasan dan Perkumpulan yang berbentuk Badan Hukum mempunyai kekuatan hukum yang sama, yaitu sama-sama dianggap sebagai subyek hukum dan dapat melakukan perbuatan hukum. Tetapi antara Yayasan dan Perkumpulan yang tidak berbentuk Badan Hukum, maka Yayasan kedudukan hukumnya lebih kuat daripada Perkumpulan sebagaimana tersebut di atas. Hak dan kewajiban yang dimiliki oleh Yayasan dan Perkumpulan yang berbentuk Badan Hukum adalah sama, yaitu sebagai berikut:

1. Hak: Berhak untuk mengajukan gugatan.

2. Kewajiban : Wajib mendaftarkan Perkumpulan atau Yayasan tersebut pada instansi yang berwenang untuk mendapatkan status Badan Hukum.

Perbedaan mendasar juga terdapat pada susunan Organ. Organ yayasan terdiri dari; Pembina, Pengawas dan Pengurus. Sementara pada perkumpulan terdiri dari Anggota, Pengurus dan Musyawarah Umum. Kewenangan Pembina dalam sebuah yayasan adalah sebagai berikut:
a. Merubah Anggaran Dasar;
b. Mengangkat dan Memberhentikan anggota Pengurus dan anggota Pengawas;
c. Menetapkan kebijakan umum Yayasan berdasarkan Anggaran Dasar Yayasan;
d. Mengesahkan program kerja dan rancangan anggaran tahunan Yayasan dan;
e. Menetapkan keputusan mengenai penggabungan atau pembubaran Yayasan.

\section{SIFAT DAN KARAKTERISTIK YAYASAN}

a. Tujuan Yayasan

Setiap organisasi, termasuk yayasan, memiliki tujuan yang spesifik dan unik yang dapat bersifat kuantitatif maupun kualitatif. Tujuan yang bersifat kuantitatif mencakup pencapaian laba maksimum, penguasaan pangsa pasar, pertumbuhan organisasi, dan produktifitas. Sementara tujuan kwalitatif dapat di sebutkan sebagai efensiensi dan 
efektivitas organisasi, manajemen organisasi yang tangguh, moral karyawan yang tinggi, reputasi organisasi, stabilitas pelyanan kepada masyarakat, dan citra perusahaan. Tujuan itu sendiri adalah suatu hasil akhir, titik akhir, atau segala sesuatu yang akan dicapai. Setiap tujuan kegiatan disebut sebagai "sasaran" atau "target".

b. Visi

Visi merupakan pandangan kedepan dimana suatu organisasi akan diarahkan. Dengan mmpunyai visi, yayasan dapat berkarya secara konsisten dan tetap eksis, antisipatif, inovatif, serta produktif. Visi adalah suatu gambaran yang menantang tentang keadaan masa depan yang berisikan cita dan citra yang ingin diwujudkan suatu yayasan.

c. Misi

Misi adalah sesuatu yang diemban atau dilaksanakan oleh suatu yayasan sebagai penjabaran atau visi yang telah ditetapkan. Dengan pernyataan misi, seluruh unsur yayasan dan pihak yang berkepentingan dapat mengetahui serta mengenal keberadaan dan peran yayasannya. Misi harus jelas dan sesuai dengan tugas pokok dan fungsi. Misi juga terkait dengan kewenangan yang dimiliki oleh yayasan berdasarkan peraturan perundangan atau kemampuan penguasaan teknologi sesuai strategi yang dipilih.

d. Sumber Pembiayaan/Kekayaan

Sumber pembiayaan yayasan berasal dari sejumlah kekayaan yang dipisahkan dalam bentuk uang atau barang. Selain itu, yayasan juga memperoleh sumbangan atau bantuan yang tidak mengikat seperti berupa:

1. Wakaf,

2. Hibah,

3. Hibah Wasiat,

4. Perolehan lain yang tidak bertentanagn dengan anggaran dasar yayasan atau peraturan perundang-undangan yang berlaku.

e. Pola Pertanggungjawaban

Pertanggungjawaban manajemen merupakan bagian terpenting bagi kredibilitas manajemen di yayasan. Tidak terpenuhinya prinsip pertanggungjawaban tersebut dapat menimbulkan implikasi yang luas.

\section{f. Struktur Organisasi Yayasan}

Struktur organisasi yayasan merupakan turunan dari fungsi, strategi, dan tujuan organisasi. Sementara itu, tipologi pemimpin, termasuk pilihan dan orientasi organisasi, sangat berpengaruh terhadap pilihan struktur birokrasi pada yayasan. Kompleksitas organisasi sangat berpengaruh pada struktur organisasi. Fungsi badan 
hukum yayasan merupakan pranata hukum bagi pencapaian tujuan tertentu dibidang sosial, keagamaan, dan kemanusiaan.

g. Karakteristik Anggaran

Anggaran merupakan artikulasi dari hasil perumusan strategi dan perencanaan strategik yang telah dibuat. Dalam bentuk yang paling sederhana, anggaran merupakan suatu dokumen yang menggambarakan kondisi keuangan yayasan yang meliputi informasi mengenai pendapatan, belanja, dan aktivitas.

h. Sistem Akuntansi

Sistem akuntansi merupakan prinsip akuntansi yang menentukan kapan transaksi keuangan harus diakui untuk tujuan pelaporan keuangan. Sistem akuntansi ini berhubungan dengan waktu pengukuran dilakukkan dan pada umumnya, bisa dipilih menjadi sistem akuntansi berbasis kas dan berbasis aktual. Pada sebuah yayasan, penekanan diberikan pada penyediaan biaya data yang disajikan dalam bentuk laporan keuangan yang menggunakan sistem akuntansi berbasis aktual yaitu akuntansi pendapatan dan biaya.

\section{KEDUDUKAN HUKUM YAYASAN}

A. Kedudukan Hukum Yayasan dalam Sistem Hukum Indonesia Yayasan adalah suatu entitas hukum yang keberadaannya dalam lalu lintas hukum di Indonesia sudah diakui oleh masyarakat berdasarkan realita hukum positif yang hidup dan berkembang dalam masyarakat Indonesia. Kecenderungan masyarakat memilih bentuk yayasan disebabkan karena:

a. Proses pendiriannya sederhana

b. Tanpa memerlukan pengesahan dari pemerintah

c. Persepsi masyarakat bahwa yayasan bukan merupakan subjek pajak

Pengakuan yayasan sebagai badan hukum berarti ada subjek hukum yang mandiri. Secara teoretis, adanya kekayaan yang terpisah, tidak membagi kekayaan atau penghasilannya kepada pendiri atau pengurusnya, mempunyai tujuan tertentu, mempunyai organisasi yang teratur, dan didirikan dengan akta notaris merupakan karakter yayasan. Ciri tersebut memang cocok dengan ciri-ciri badan hukum pada umumnya, yaitu adanya kekayaan yang terpisah, tujuan tertentu, kepentingan sendiri, dan organisasi yang teratur. Berdasarkan hukum kebiasaan dan asumsi hukum yang berlaku umum di masyarakat, ciri-ciri yayasan dapat dirinci sebagai berikut: 
1. Eksistensi yayasan sebagai entitas hukum di Indonesia belum didasarkan pada perturan perundang-undangan yang berlaku.

2. Pengakuan yayasan sebagai badan hukum belum ada dasar yuridis yang tegas, berbeda halnya dengan PT. Koperasi, dan badan hukum yang lain.

3. Yayasan dibentuk dengan memisahkan kekayaan pribadi pendiri untuk tujuan nirlaba, tujuan religius, sosial keagamaan, kemanusiaan, dan tujuan ideal yang lain.

4. Yayasan didirikan dengan akta notaris atau dengan surat keputusan pejabat yang bersangkutan dengan pendirian yayasan.

5. Yayasan tidak memiliki anggota dan tidak memiliki oleh siapapun, namun memunyai pengurus atau organ untuk merealisasikan tujuan yayasan.

6. Yayasan mempunysi kedudukan yang mandirir sebagai akibat adanya kekayaan yang terpisah dari kekayaan pribadi pendiri atau pengurusnya, dan mempunyai tujuan sendiri yang berbeda atau lepas dari tujuan pribadi pendiri atau pengurus

7. Yayasan diakui sebagai badan hukum seperti halnya orang, sebagai subjek hukum mandiri yang dapat menyandang hak dan kewajiban mandiri, didirikan dengan akta, dan didaftarkan di kantor kepaniteraan pengadilan negeri setempat

8. Yayasan dapat dibubarkan oleh pengadilan dalam kondisi pertentangan tujuanyayasan dengan hukum, likuidasi, dan pailit. Berdasarkan UU No. 16 Tahun 2001, yayasan telah diakui sebagai badan hukum privat dimana subjek hukum para pendiri atau pengurusnya. Sebagai subjek hukum mandiri, yayasan dapat menyandang hak dan kewajiban, menjadi debitor maupun kreditor, dan melakukan hubungan hukum apapun dengan pihak ketiga. Legalisasi badan hukum menurut UU Yayasan adalah saat akta pendiriannya, yang dibuat di hadapan Notaris, disahkan oleh menteri Hukum dan Perundang-undangan dan HAM. Yayasan yang tidak menyesuaikan Anggaran Dasarnya dalam jangka waktu 5 tahun, dapat dibubarkan berdasarkan putusan pengadilan atas permohonan kejaksaan atau pihak yang berkepentingan.

B. Yayasan sebagai Entitas hukum privat

Saat ini ada banyak sekali yayasan yang berdiri di Indonesia dengan berbagai bidang yang digelutinya. Ditinjau dari cara pendirian atau pembentukannya, yayasan dapat dibagi menjadi dua, yaitu yayasan yang didirikan oleh penguasa atau pemerintah, termasuk BUMN serta BUMD dan yayasan yang didirikan oleh individu atau swasta. Yayasan yang didirikan oleh pemerintah, sebelum keluarnya UU yayasan, disahkan 
dengan surat keputusan dari pejabat yang berwenang dan atau akta notaris. Kekayaan awal yayasan seperti ini dapat diambilkan dari kekayaan negara yang "dipisahkan" atau" dilepaskan penguasaannya" dari pemerintah dan dari kekeyaan pribadi. Yayasan tersebut akan berada dalam bingkai hukuman privat dengan segala konsekuensi yuridisnya. Kedudukan kekayaan negara yang "dipisahkan" atau "dile paskan penguasaannya" itu secara yuridis mirip dengan "hibah", sehingga segala konsekuesi penggunaan, pengelolaan, dan pengawasan atas kekayaan tersebut akan lepas sama sekali dari pihak yang memberi atau yang menghibahkan. Yayasan yang didirikan oleh swasta atau perorangan, menurut UU yayasan, harus didirikan dengan akta Notaris. Kekayaannya di pisahkan dari milik para pendiri atau pengurus yayasan yang bersangkutan. Akta notaris tersebut harus didaftarkan di kantor kepaniteraan pengadilan negeri setempat. Dewasa ini, banyak yayasan didirikan dengan tujuan yang berbeda dan menyimpang dari tujuan semula, yaitu sebagai usaha yang menguntungkan seperti sebuah perusahaan yang melakukan lalu lintas dagang. Unsur-unsur menjalankan perusahaan, seperti dokumen perusahaan, mempunyai izin usaha, dikenai pajak, menggaji pengurus, memperhitungkan atau menghitung untung rugi lalu mencatatnya dalam pembukuan adalah ciri-ciri suatu kegiatan yang berbentuk hukum perusahaan. Tanda-tanda yayasan mulai menyimpang dari tujuan semula, yang secara nyata, dituangkan dalam anggaran dasar suatu yayasan. Dalam anggaran dasar diatur beberapa hal seperti keanggotaan yayasan yang abadi dimana pendiri mempunyai kekuasaan mutlak dan abadi bahkan kedudukannya dapat diwariskan. Yayasan tersebut bergerak dalam bidang pendidikan. Pendiri berasumsi bahwa keuntungan yang diperoleh suatu saat akan dikendalikan. Oleh karena itu, untuk mengamankan kedudukannya, di dalam anggaran dasar, kedudukan pendiri di atur sebagai abadi, dapat diwariskan, dan mempunyai hak veto. Dengan keluarnya UU yayasan, eksistensi dan landasan yuridis Yayasan sebagai entitas hukum privat tidak perlu dipermasahkan lagi atau tidak perlu diragukan. Yayasan pada hakikatnya dalah kekayaan yang dipisahkan dan diberi sattus badan hukum. Sebagai subyek hukum, organ yayasan difungsikan dengan sebutan pembina, pengawas, dan pengurus. Analog dengan hukum PT, kedudukan dewan pembina itu sama dengan RUPS (rapat umum pemegang saham). Pengawas sama dengan komisaris, dan pengurus sama dengan direksi. Dengan demikian, yayasan pada hakikatnya adalah:

a. Harta kekayaan yang dipisahkan.

b. Harta kekayaan tersebut diberi badan hukum.

c. Keberadaannya untuk tujuan tertentu di bidang sosial, manusia dan keagamaan. 
Secara teoritis, yayasan dapat didirikan oleh satu orang, dua orang, atau lebih, yayasan tidak mempunyai anggota (semacam pemegang saham dalam PT) dan eksistensinya hanya diperuntukkan guna mencapai tujuan tertentu dalam bidang sosial, kemanusiaan, dan keagamaan. Oleh karena itu, semua kegiatan yayasan harus diabadikan ke pencapaian tujuan tersebut. UU yayasan menegaskan hal ini dengan melarang pembagian hasil usaha kepada organ yayasan, dengan ancaman pidana. Praktek peradilan selama ini terfokus pada syarat pemisahan harta kekayaan akta notaris sebagai syarat pendirian yayasan. Syarat pemisahan harta kekayaan sangat banyak dijadikan alasan menurut pengurus yayasan, karena pada umumnya hasil usaha yayansan telah dijadikan obyek perebutan dalam kepengurusan. Anak keturunan para pendiri sering menjadi pihak yang berperkara, karena kelemahan organisasi yayasan nampak dengan alasan subjektif. Isi akta pendirian sering dijadikan alasan untuk mengalihkan harta kekayaan yayasan, seolah-olah akta pendirian itu dapat diubah setiap saat sesuai dengan keinginan pengurus yayasan. Praktek-praktek seperti diuraikan sebelumnya mulai diluruskan dengan UU yayasan. Yayasan akan ditempatkan pada kedudukan yuridis sebagai badan hukum yang berfungsi sosial, idiil, dan keagamaan. Yayasan boleh menggunakan kegiatan usaha, boleh mempunyai sisa hasil usaha, tetapi tidak boleh profit orientet sudah seperti halnya PT. Sisa hasil usaha belum ada, tetapi tidak boleh dibagi kepada organ yayasan. Yayasan mendirikan badan usaha, misalnya PT, dengan modal usaha maksiamal 25\% dari seluruh aset. Yayasan harus membuat laporan keuangan, diamana laporan keuangan itu harus diperiksa oleh akuntan pubik untuk yayasan yang memilik aset seniali Rp. 20 milyar lebih dan yang mendapat bantuan senilai Rp. 500 juta ke atas. Laporan keuangan tersebut harus diumumkan dan tembusannya harus disampaikan kepada Menteri

\section{PENGEMBANGAN ORGANISASI YAYASAN}

Pada dasarnya, yayasan merupakan suatu organisasi sehingga pendekatan yang digunakan dalam pengembangannya juga tidak jauh berbeda dengan pendekatan yang digunaka dalam pengembangan organisasi pada umumnya. Pengembangan yayasan adalah suatu usaha jangka panjang untuk memperbaiki proses-proses pemecahan masalah dan pembaharuan organisasi, terutama melalui manajemen budaya organisasi yang lebih efektif dan kolaboratif dengan teanan khusus pada budaya tim kerja formal dengan bantuan pengantar perubahan, katalisator, dan penggunaan teori serta teknologi ilmiah keperilakuan terapan termasuk riset kegiatan. Melaui proses pembaharuan, para pengelolah yayasan menyesuaikan gaya dan tujuan pemecahan masalah untk memenuhi 
berbagai permintaan perubahan lingkungan yayasan. Jadi, salah satu tujuan pengembangan yayasan adalah untuk memperbaiki proses pembaharua itu sendiri, sehingga para pengelolah dapat lebih cepat mengambil gaya manajemen yang sesuai dengan masalah-masalah baru yang dihadapi. Riset kegiatan merupakan metode perubahan organisasi dalam menjalankan aspek-aspek yayasan yang perlu diperbaiki. Kegiatan riset meliputi :

a. Diagnosis pendahuluan terhadap masalah pengantar perubahan pengembangan yayasan,

b. Pengumpulan data untuk mendukung diagnosis,

c. Umpan balik datar kepada para anggota pengelola,

d. Eksplorasi data oleh para anggota pengelola,

e. Perencanaan kegiatan yang tepat,

f. Pengambilan kegiatan yang tepat.

\section{A. Teknik-teknik Pengembangan Yayasan}

Teknik pengembangan organisasi dapat diguanakan untuk memperbaiki efektifitas perseorangan, hubungan pekerjaan antara 2 atau 3 individu, pemfungsian kelompokkelompok, hubungan antara kelompok atau efektifitas yayasan secara keseluruhan. Teknik yang digunakan untuk kelompok sasaran yaitu:

- Pengembangan organisasi untuk perseorangan,

- Pengembangan organisasi untuk dua atau tiga orang,

- Pengembangan organisasi untuk tim atau kelompok,

- Pengembangan organisasi untuk hubungan antar kelompok,

- Pengembangan organisasi untuk organisasi keseluruhan.

\section{B. Grid OD (Grid Organizational Development)}

Salah satu teknik pengembangan organisasi yaitu Grid OD didasarkan atas kisi manajerial dari Robert Blake dan Jane Mouton. Kini manajerial mengidentifikasika berbagai kombinasi produksi dan karyawan, agar perhatian terhadap variabel tersebut meningkat dalam grid OD pengantar perubahan mempergunakan daftar pertanyaan untuk menentukan gaya pada manajer atau pengelola sekarang, membantu mereka untuk menguji kembali gayanya, dan bekerja menuju efektivitas. 


\section{Metode Pengembangan Organisasi OCA (Organizational Capacity Assessment)}

Salah satu metode pengembangan organisasi yang lain adalah Penjajakan kapasitas organisasi. OCA merupakan metode pengembangan organisasi sejak dari menyusun perangkap, melakukan penjajakan, hingga menyusun rencana pengembangan organisasi serta pelaksanaan rencana pengembangan dan evaluasi atas pelaksanaan rencana tersebut. Seluruh tahapan itu dilakukan oleh seluruh bagian yang ada dalam organisasi atau secara representatif mewakili seluruh bagian yang ada. Prinsip OCA adalah partisipatif dalam seluruh proses pelaksnaan OCA serta kerahasiaan atas proses dan hasil OCA.

\section{BIDANG USAHA YANG DIPERBOLEHKAN DALAM YAYASAN}

Sesuai Pasal 3 ayat (1) UU No.16 Tahun 2001 tentang Yayasan (“UU Yayasan”), suatu Yayasan dapat melakukan kegiatan usaha untuk menunjang pencapaian maksud dan tujuannya dengan cara mendirikan badan usaha dan atau ikut serta dalam suatu badan usaha. Dalam penjelasan pasal ini disebutkan bahwa ketentuan dalam ayat ini dimaksudkan untuk menegaskan bahwa Yayasan tidak digunakan sebagai wadah usaha dan Yayasan tidak dapat melakukan kegiatan usaha secara langsung tetapi harus melalui badan usaha yang didirikannya atau melalui badan usaha lain dimana Yayasan menyertakan kekayaannya (penjelasan Pasal 3 ayat [1] UU No. 28 Tahun 2004 tentang Perubahan atas UU No. 16 Tahun 2001 tentang Yayasan). Mengenai jenis kegiatan usaha apa saja yang boleh dilakukan badan usaha yang didirikan Yayasan, sesuai Pasal 7 ayat (1) UU Yayasan, badan usaha tersebut harus sesuai dengan maksud dan tujuan pendirian yayasan. Hal ini ditegaskan pula dalam Pasal 8 UU Yayasan bahwa kegiatan usaha dari badan usaha sebagaimana dimaksud dalam Pasal 7 ayat (1) harus sesuai dengan maksud dan tujuan Yayasan serta tidak bertentangan dengan ketertiban umum, kesusilaan, dan atau peraturan perundang-undangan yang berlaku. Lebih jauh disebutkan dalam penjelasan Pasal 8 UU Yayasan bahwa kegiatan usaha dari badan usaha Yayasan mempunyai cakupan yang luas, termasuk antara lain hak asasi manusia, kesenian, olah raga, perlindungan konsumen, pendidikan, lingkungan hidup, kesehatan, dan ilmu pengetahuan. Dari penjelasan Pasal 8 tersebut, dapat diambil kesimpulan bahwa bidang usaha yang bisa didirikan oleh Yayasan sebenarnya tidak hanya terbatas pada bidangbidang yang telah disebutkan melainkan bisa lebih luas lagi. 


\section{PEMBUBARAN YAYASAN}

A. Beberapa hal berikut dapat mengakibatkan bebarnya yayasan:

1. Jangka waktu yang ditetapkan dalam anggaran dasar berakhir.

2. Tujuan yayasan yang ditetapkan dalam anggaran dasar telah tercapai atau tidak tercapai.

3. Putusan pengadilan yang telah memperboleh kekuatan hukum tetap berdasarkan alasan:

- Yayasan melanggar ketertiban umum

- Tidak mampu membayar hutangnya setelah dinyatakan pailit

- Harta kekayaan yayasan tidak cukup untuk melunasi hutangnya setelah pernyataan pailit

B. Pembubaran yayasan diikuti dengan proses likuidasi (pemberesan kekayaan) yayasan yang dilakukan oleh likuidator apabila hasil likuidasi menghasilkan sisa kekayaan dari yayasan maka sisa kekayaan itu kemudian diserahkan kepada yayasan lain yang mempunyai kesamaan kegiatan dengan yayasan yang bubar atau diserahkan kepada badan hukum lain dengan kegiatan yang sama. Atau dapat juga sisa kekayaan yayasan yang bubar diserahkan kepada negara.

\section{CONTOH MASALAH YAYASAN}

A. Mesin Pencetak Uang NII ALZAYTUN Berkedok Yayasan Yatim Dan Dhuafa Fikri Akbar Sebuah fenomena yang amat memiriskan belakangan ini, banyak sekali propaganda yang dilakukan para jamaah NII ALZAYTUN guna menempuh target futuh atau kemenanganya. Para korbannya pun tetap saja para generasi muda yang punya semangat juang tinggi akan tegaknya syariat Islam di bumi Indonesia tercinta ini. Kini mereka mulai menampakan wujudnya walaupun dengan muka yang berbeda ( kedok ), namun anehnya mereka berkonspirasi dengan orang yang dianggap kafir ( RI ). Salah satunya adalah dengan kedok yayasan fakir miskin atau yatim piatu yang tersebar di seluruh Nusantara, mereka mencari mangsa di tempat tempat keramaian, misalnya dengan proposal keinstansi pemerintah maupun swasta, mall mall, terminal, pasar, halte bus way, stasiun kereta api maupun KRL, tempat parkiran masjid masjid, dll, Biasanya mereka membawa sebendel proposal, ada juga yang dengan sistem amplop yang sampelnya Yayasan tertentu dengan dibagi bagikan dan ada juga yang langsung menyodorklan kwitansi sumbangan dengan nominal tertentu yang alasanya guna kepentingan pembangunan sarana sosial. 
Belakangan ini banyak sekali pengaduan dari korban NII ALZAYTUN, yang mereka rata rata pernah dipekerjakan sebagai team pencari amal yang hasilnya adalah untuk pesantren ALZAYTUN di Indramayu Jawa Barat. Salah satunya adalah Yayasan Fikri Akbar, yang berpusat di Jawa Timur, Yayasan Nurul Ulum, yang berpusat di Godean Sleman Jogjakarta, Yayasan Nurul Jannah, di Jakarta, dan Yayasan lain diseluruh Nusantara. Namun para anggotanya menyebar ke seluruh penjuru tanah air dalam mencari sumbangan, kini mereka juga merangkul beberapa pihak yang diantaranya adalah tokoh masayarakat dan orang terpandang di sekitarnya. Entah karena alasan tidak tahu atau apa memang sudah ada konspirasi diantara mereka. Apa karena propaganda para jamaah NII Alzaytun ini sangat hebat ya sehingga orangorang yang punya pendidikan tinggi dan punya jabatan bergensi itu bisa terlibat dalan jaringan NII ALZAYTUN. Memang pada dasarnya mereka tidak dengan terangterangan mengusung ideologi Negara Islam Indonesia, mereka kemas dalam bentuk acara seminar, klinik, lembaga pendidikan, dll sehingga tak tercium gerakan NII nya, namun kalau dilihat dari personilnya adalah mereka semuanya yang ada dalam kepengurusan Yayasan Fikri Akbar adalah para jamaah dan aparat aktif NII ALZAYTUN. Jika dikaji mendalam, ini adalah kasus perdagangan manusia dan perbudakan yang harus dihentikan, para jamaah NII dengan dalih berjuang menegakan syariat Islam rela menghabiskan waktunya guna mencari dana dan mencari target rekrutmen anggota NII baru. Salah satu contoh propaganda Yayasan Fikri Akbar yang hasilnya kini mencapai angka yang cukup tinggi. Yayasan Fikri Akbar merupakan Yayasan yang bergerak dibidang pendidikan dan sosial adapun program-program yang saat ini sedang kami kerjakan antara lain:
a. Pendirian Panti Asuhan FIKRI AKBAR
b. Pendidikan dan pelatihan anak jalanan
c. Bimbingan belajar bagi anak kurang mampu
d. Santunan anak asuh, Lansia dan Dhuafa'
e. Pengobatan dan khitanan massal gratis
f. Klinik murah untuk dhuafa'

Di kantor pusat Yayasan Fikri Akbar yaitu di Jalan S. Parman V 96, Waru, Sidoarjo, kami mengadakan pelayanan praktek pengobatan yang ditangani oleh Dokter Umum dan perawat kesehatan. Jam praktek antara pukul 08.00 - 12.00 dan pukul 17.00 -20.00. Dibukanya praktek pengobatan ini merupakan upaya kami dalam mempersiapkan berdirinya sebuah Klinik yang kedepannya selain melayani masyarakat umum juga dapat membantu masyarakat yang kurang mampu agar dapat 
memperolah pelayanan kesehatan yang semestinya. Kami juga akan mengadakan pelayanan kesehatan keliling dalam waktu dekat ini. Semoga saja langkah awal yang talah kami lakukan ini mendapat ridho dari Allah SWT, karena semua itu kami lakukan dalam upaya semata-mata untuk beribadah kepada Allah SWT. Semoga juga apa yang kami cita-citakan dapat terlaksana dengan segera dengan do'a dan ikhtiar dari para pengurus, relawan, donatur, serta semua pihak yang berkenan serta mendukung apa yang sedang dan akan kami programkan.

Melihat realitas tersebut akankah kiat terus diam membisu melihat saudara seagama kita telah dipolitisir dan dimanfaatkan semangatnya untuk kepentingan Panji Gumilang dan kelompoknya, apa karena keluarga kita tidak terkena imbas langsung terjerat gerakan makar NIII ALZAYTUN ini sehingga kita ga punya semangat untuk menyelamatkan saudara kita yang sedang terjebak di NII ALZYTUN. Ingat, setiap hari mereka merekrut jamaah baru, mereka seperti mesin penghancur masal yang akan mencari target dan harus berhasil sampai sang target terperangkap dalam komunitas mereka. Jika tidak waspada terget berikutnya barangkali anda atau keluarga anda. Kini para jamaah NII ALZAYTUN lebih diperas lagi karena mereka lagi punya hajat besar guna men sukseskan 5 caleg yang diusung NII AL-ZAYTUN di Partai Republikan yaitu :

a. H. Imam Prawoto. Dapil Banten I (Kabupaten dan Kodya Tanggerang), anak Panji Gumilang

b. Muhammad Sholeh Aceng, SH. Dapil Banten III (Pandeglang dan Lebak),

c. Drs. Miftah. Dapil Jawa Barat III (Kodya Bogor dan Cianjur), keponakan Panji Gumilang.

d. Dr. Dani Kadarisman. Dapil Jabar X (Kuningan, Banjar dan Ciamis), Dokter ALZAYTUN

e. Ir. M. Asrurifak, MT., Caleg DPR-RI Dapil Jatim X Lamongan - Gresik Salah satunya adalah putra presiden NII ALZAYTUN Panji Gumilang yait Imam Prawoto untuk dapil Banten Tangerang. Semua jamaah NII ALZAYTUN diwajibkan mencoblos salah satu caleg-caleg di Partai Republikan, bahkan kasus penggelembungan suara seperti di ALZAYTUN bakal terulang kembali, 5 caleg Partai Republikan yang di usung NII AL-ZAYTUN pasti suaranya bakal meledak di daerah mereka karena para jamaah NII ALZAYTUN yang berada di luar dapil mulai saat ini sudah mulai datang ke setiap kelurahan masing masing untuk minta surat pindah atau pengantar untuk mencoblos di daerah dapil yang mereka kehendaki, tentunya tergantung mana yang deket dengan caleg di dapil mereka. 


\section{B. Eksekusi Yayasan Al-Madinah}

Yayasan Al-Madinah yang bergerak dalam bidang pendidikan, sosial dan keagamaan ini, menampung 45 anak yatim piatu. Akibat eksekusi itu, puluhan anak yang dibina itu terpaksa harus mengungsi. "Dari sisi HAM, saya melihat bahwa setelah digusur ada 45 anak yang berada di yayasan itu mengungsi di salah satu masjid, namun lokasi itu juga sudah dipagari. Eksekusi ini adalah indikasi tindakan pelanggaran HAM. Hak atas pendidikan, hak atas keadilan dan hak atas rasa aman," tandas Lawalatta kepada wartawan di Ambon, Senin (27/6). Lawalatta mengungkapkan, pihaknya bersama Yayasan Al-Madinah telah melaporkan eksekusi oleh PN Ambon itu kepada Departemen Hukum dan HAM Maluku. "Direncanakan pada 5 Juli 2011 mendatang Komnas HAM Pusat akan datang ke Departemen Hukum dan HAM Maluku dan akan bertemu dengan pihak pengadilan, dan Ketua Yayasan Al-Madinah supaya kita bicarakan lebih jelas menyangkut penggusuran atau eksekusi tersebut," katanya. Berdasarkan laporan pelanggaran HAM yang dilaporkan Koordinator Pelaksana Yayasan Al-Madinah, Mustari Muhammad yang salinannya diterima Siwalima, Senin (27/6), menyebutkan, Yayasan Al-Madinah telah menjadi korban pengrusakan dan pembongkaran secara bersama-sama dengan alasan eksekusi yang dilakukan oleh PN Ambon atas permohonan yang diajukan oleh H Latief Hatala. Eksekusi tersebut telah mengakibatkan satu bangunan asrama putra panti asuhan dan bangunan sekolah Taman Kanak-Kanak serta gedung sekolah Madrasah Ibtidaiyah beserta segala perabotan dan peralatan sekolah dihancurkan, sehingga telah melantarkan anak-anak binaan pantai asuhan Yayasan Al Madinah sebanyak 45 orang yang kehilangan tempat tinggal dan siswa Madrasah Ibtidaiyah sebanyak 35 orang tidak dapat meneruskan pendidikannya serta janda dua orang yang gelisah dengan keberadaannya.Tindakan pengerusakan dan pembongkaran secara bersama-sama tersebut sengaja dilakukan terhadap Yayasan Al-Madinah, karena sebelumnya Yayasan Al-Madinah menolak untuk tunduk menyerahkan yayasan beserta assetasetnya kepada H. Latief Hatala yang mengajukan permohonan eksekusi atas Dusun Warasia ke PN Ambon serta menolak memberikan pembayaran ganti rugi. Menurut Mustari, Yayasan Al-Madinah tidak terkait dengan putusan Peninjauan Kembali Mahkamah Agung (MA) nomor 122 PK/Pdt/2010 tanggal 30 Juli 2010 dalam perkara antara Hatala dan Keluarga Masawoy. Tanah milik Yayasan Al-Madinah terletak dan berada jauh di luar tanah yang disengketakan tersebut. Yayasan Al-Madinah menolak permintaan ganti rugi karena tidak pernah menempati tanah milik H Latief Hatala, karena areal bidang tanah yang ditempati oleh yayasan tersebut dibeli dari Keluarga 
Masawoy secara sah berdasarkan bukti-bukti kepemilikan yang sah. Untuk diketahui, PN Ambon pada Kamis (16/6) melakukan eksekusi terhadap lahan di Dusun Warasia yang terletak di Desa Batu Merah, Kecamatan Sirimau, Kota Ambon. Turut hadir dalam proses eksekusi tersebut, yakni Raja Batu Merah, Awat Ternate. Eksekusi terhadap Dusun Warasia merupakan akhir dari sengketa perkara Nomor 01 Tahun 2006 antara Acmad Hatala selaku pemohon eksekusi melawan Achmad Masawoy dan kawan-kawan. Tanah seluas 150 Ha tersebut sebelum dieksekusi telah melalui proses hukum yang cukup panjang dan berakhir dengan Peninjauan Kembali (PK) yang dimenangkan pihak Hatala. Untuk diketahui, Dusun Warasia rata-rata dihuni oleh pengungsi. Sebanyak 139 KK yang mendiami objek sengketa tersebut, 44 KK merupakan pengungsi, sedangkan sisanya merupakan pihak lain yang bukan pengungsi. Namun demikian, sehari sebelum pelaksanaan eksekusi dilakukan, oleh warga melalui ketua-ketua RT sudah melakukan mediasi dengan pihak PN dengan harapan agar eksekusi paksa tidak dilaksanakan dan mohon penyelesaian secara kekeluargaan. Mediasi dilakukan di ruang Panitera Sekretaris PN Ambon dengan dihadiri pemohon eksekusi H. Acmad Hatala, Ketua PN, Arthur Hangewa dan pihak Polres Ambon dan Pp Lease beserta staf. Hasil dari mediasi tersebut terjadi kesepakatan antara RT yang mewakili warga dengan pemohon eksekusi, yakni terhadap bangunan rumah milik pengungsi yang berada di atas objek sengketa tidak dieksekusi, tapi pengungsi mempunyai kewajiban setiap kapling ditetapkan seharga Rp 5 juta. Hasil kesepakatan itu diteruskan oleh RT setempat dan telah dilakukan pertemuan antara warga yang berada di atas objek sengketa dengan RT untuk dilakukan sosialisasi dan ternyata mereka siap dan tunduk pada putusan pengadilan. 


\section{BAB III}

\section{PENUTUP}

\section{A. KESIMPULAN}

Yayasan adalah suatu badan hukum yang mempunyai maksud dan tujuan bersifat sosial, keagamaan dan kemanusiaan, didirikan dengan memperhatikan persyaratan formal yang ditentukan dalam undang-undang. Di Indonesia, yayasan diatur dalam UndangUndang Nomor 28 Tahun 2004 tentang Perubahan atas Undang-Undang Nomor 16 Tahun 2001 tentang Yayasan. Rapat paripurna DPR pada tanggal 7 September 2004 menyetujui undang-undang ini, dan Presiden RI Megawati Soekarnoputri mengesahkannya pada tanggal 6 Oktober 2004. Dalam pelaksanaannya yayasan dilakukan oleh tiga organ yaitu pembina, pengawas dan pengurus.

\section{B. SARAN}

Sebaiknya yayasan dalam melakukan ttindakan harus bertnggung jawab agar tidak merugikan orang lain. Dan apabila ada yayasan yang belum terdaftar sebaiknya yayasan tersebut harus ditindak secara tegas sesuai dngan hukum yang berlaku. 